\title{
PRACTICAL ASPECTS OF INVENTORY AND RECEIVABLES FINANCING
}

\author{
RAYMOND W. BuRMaN*
}

I

The financing of accounts receivable and inventory as we know it today is still in its figurative 'teens. Although factoring, which was the forerunner of the assignment of receivables for value, has been in existence for many decades, and in spite of the fact that ancient Babylon was acquainted with "warehouse receipts," the development of our present style of operation has not yet reached its business majority. The workings of this type of fund-lending, therefore, cannot be reduced to a closed-end manual. It is still feeling its way through the labyrinthian maze of today's business world; it is new and growing; and it is constantly changing shape. What I will say in this article, therefore, is only a progress report, subject to review and revision as the boy grows into manhood.

A word about the early background of factoring is necessary if we are to understand what was to follow later. ${ }^{1}$ During the latter part of the nineteenth century the use of commission agents in this country by overseas firms to facilitate distribution was carried over into the pattern of domestic commerce. While these commission agents were primarily sales-concentration points, their value to a manufacturer or shipper was greatly enhanced from a credit standpoint because of their knowledge of and association with the ultimate buyer. Shippers, far removed from their customers, came to depend more and more upon their agents for information regarding the worthiness of purchasers. Credit agencies being non-existent, and communications being less easy than we know them today, it was an impossible job for any shipper to be acquainted with his customer's ability to pay. As time went on, this situation became more pronounced until there naturally evolved the early stages of factoring. The commission agent became less of a salesman and more a guarantor of credit. And, as he guaranteed the credit, he began to discount the shipper's invoices and collect from the buyer himself. He was then a private banker.

At what point the mere assignment of receivables evolved from the factoring arrangement it is difficult to determine. Suffice it to say that the new plan did not generally become known until just prior to World War $\mathrm{I}$, although it is recorded that Arthur R. Jones and John L. Little began dealing in receivables in a general way in Chicago about rgo4, later founding the Mercantile Credit Company. Also in 1904, G. G. Foster founded the Fidelity Contract Company in Rochester, New

- Mr. Burman has been associated with the commercial finance industry for over 26 years. He is the President of American Business Credit Corporation, New York City, and Coin Machine Acceptance Corporation, Chicago. $\mathrm{He}$ is also President of the trade organization of the industry, National Conference of Commercial Receivable Companies, Inc.

${ }^{2}$ William Hurd Hillyer, Jases Talcott, Merchant, c. VI (I937). 
York, later to become the present Bankers Commercial Corporation, of which Mr. Foster is still Chairman of the Board. In 1908, Henry Ittleson, now Chairman of C. I. T. Financial Corporation, founded the Commercial Credit and Investment Company at St. Louis, later to become C. I. T. Financial Corporation. Another pioneer in the field was A. E. Duncan, who in rgio formed the Manufacturers' Finance Company, forerunner of Commercial Credit Company. ${ }^{2}$ These ventures proved profitable, and were soon followed by more organizations of the same type.

Almost from the beginning, receivables financing encountered opposition from many quarters. As the business proved itself sound and profitable, there inevitably arose groups of opportunists to prey upon industry's needs for funds, and the unhappy experiences of some businessmen engendered for the financing plan much ill will which it has taken years to rectify. In addition, banks often regarded it askance, placing no faith in it until after the first World War. It was charged that this new form of credit was unorthodox; that it would result in a breakdown of sound credit principles and lead to such reckless expansion as to affect adversely the economy of our country. Critics, however, failed to take into account the fact that the founders of early finance companies made most thorough examinations of their customers' condition, maintained efficient systems of auditing and checking, and certainly had no more desire to become involved in the liquidation of a debtor than any other financial institution. In any event, the finance companies overcame these obstacles and eventually proved their worth to the economic community.

The inherent value in receivables financing is the same today as it was in those early, doubtful days. It releases to an entrepreneur the working capital bound up in monies due him from his customers, permits him to increase his sales potential, and enables him to pay bills more promptly. It is not a panacea, nor a substitute for fixed equity, but it does provide him with additional cash which might otherwise be lying idle unnecessarily. It makes available a varying flow of funds directly in proportion to the sales movements of the business, and is the answer to the requirements of seasonal fluctuations. Companies which find themselves unable to borrow a sufficient amount on an unsecured basis can often realize more cash in the assignment of their receivables, provided that they meet credit requirements in other respects; and, to the extent of the lender's advance, they obtain the added competitive advantage of selling merchandise for cash.

When I say that the industry is young, I do not mean to imply that it is small or in any sense untested. It is estimated that the volume of accounts receivable financed by all types of agencies in 1946 exceeded $4 \frac{1}{2}$ billion dollars, compared to about $2 \frac{1}{2}$ billions in r94I-a stupendous amount measured by any standard. ${ }^{3}$ Of this amount, banks, which in more recent years have entered the field with a zest, accounted for nearly half, while the remainder is attributed to commercial finance companies. Since the latter have pioneered in the field, my analysis will be made from that vantage point. The finance-company phase of the business has been re-

2 William H. Grimes, The Story of Commercial Credit Company 5 (1946).

- Ramand J. Saulnier and Netl H. Jacoby, Accounts Receivable Financing 4 (I943). 
cently joined together for mutual benefit through the medium of the trade association for the industry, the National Conference of Commercial Receivable Companies, Inc. This Conference in its short life has already done much to foster good will in the business community through the compiling of statistics, the prevention of undesirable legislation by the uninformed, and its attention to many other industrywide problems. It is becoming daily an increasing factor in the healthy development of commercial finance. ${ }^{4}$

Factoring in its essence consists of the guarantee of credit through the medium of purchasing of accounts receivable. The assignment of accounts receivable as collateral for borrowings is an entirely different process, and necessarily results in far different considerations. Under the latter plan, which is the main subject of this discussion, the borrower merely pledges a certain account, or accounts, to the lender, who advances a predetermined percentage of the net value of that account in dollars. When the borrower's customer remits payment to him, the check is forwarded in its original form by endorsement to the financial agency, which cashes it in payment of its loan, returning the surplus to the borrower. This, in its crudest terms, is known as non-notification funancing, since the borrower's customer is not notified of the arrangement and has no interest in it. In certain circumstances, it is considered advisable to inform the debtor of the arrangement and to have him forward his remittance directly to the financing agency; this is known as notification financing. This notification method is obviously safer from the lender's point of view, but is not as popular as the nonnotification plan, since many borrowers do not desire to publicize their financing arrangements to customers, nor to allow someone else to collect in their stead.

There are at present three different types of state laws governing the legal validity of accounts-receivable assignments: First, so-called validation statutes, whereby the mere assignment by means of a legal instrument is sufficient to convey title as against any other creditor. This is the most popular method and is currently growing in favor, as witness the passage of legislation in this direction by several commercially important states in the past several years. ${ }^{5}$ Second, recordation statutes, which require recording with local authorities of a notice of intent to assign accounts receivable. ${ }^{6}$ This requirement has been found by discerning students to have served no useful purpose. Third, bookmarking statutes, ${ }^{7}$ which require marking of the borrower's ledger pages to indicate the assignment of any individual

\footnotetext{
- Sec Proceedings of Third Annual Convention of the Commercial Finance Industry, October 20-2 $\mathrm{I}$, 1947, under auspices of National Conference of Commercial Receivable Companies, Inc., 29 Broadway, New York, N. Y.

"At the writing twenty-one states have non-notification statutes or case law of this type: Alabama, Arkansas, Connecticut, Illinois, Indiana, Kentucky, Maine, Maryland, Massachusetts, Michigan, Minnesota, New Hampshire, New Jersey, New York, North Dakota, Oregon, Rhode Island, South Dakota, Virginia, West Virginia, and Wisconsin. Four additional states have notification requirements: Louisiana, Mississippi, Tennessee, and Vermont.

o Twelve states presently have recording statutes: California, Colorado, Florida, Idaho, Missouri, North Carolina, Ohio, Oklahoma, South Carolina, Texas, Utah, and Washington.

${ }^{7}$ Only two states now require bookmarking: Pennsylvania and Georgia.
} 
receivable as notice to anyone reviewing the ledger. ${ }^{8}$ The bookmarking statute has been a thorn in the side of the borrower without accomplishing any purpose of note, while the recordation law has placed an unnecessary impediment in his wayagain without apparent benefit, since creditors normally cannot and do not continuously investigate the records of local jurisdictions for information regarding the assignment of accounts receivable.

In accepting a client for secured financing, a lender considers most thoroughly the over-all soundness of its prospect and the purpose for which its funds are to be used, but it necessarily places the greatest emphasis upon the collateral to be offered. This is true because the secured lender often makes available a larger pool of money than would a lender on an ordinary unsecured basis, and consequently would, without such attention to the security, leave itself open to larger losses in the event of bankruptcy or reorganization. In spite of this fact, however, commercial finance companies in particular should customarily make the most thorough examinations of the prospect's background, product, and records. Such investigations are repeated yearly after the original consummation of the loan, while periodically during the year less detailed audits are required to show an interim picture with respect to the status of the loan itself.

It has been emphasized that the security for an accounts-receivable loan is a lender's foremost consideration. In general, the integrity of the security is controlled in two ways: (I) original evaluation, and (2) supervision of collateral. These two factors embrace the very essence of accounts-receivable financing, and I should like to discuss them at some length.

By "original evaluation" I refer to the determination of the gross worth of the portfolio of receivables as a unit, without regard to separate invoices which may or may not have full value in themselves. ${ }^{9}$ Thus, the financial agency will consider the types of customers from the standpoint of ability to pay. It will review in detail the historical data with respect to returns and allowances, discounts, etc., in order to arrive at a net valuation under normal operating circumstances. Finally, it will scrutinize carefully any percentage concentration in a small group of debtors. From these determinations, together with a number of other lesser ones, a financier may arrive at a normal percentage of collectible dollars, and may establish criteria for its operations during the term of the loan. In this way, after leaving a margin for error, it may reach a "liquidation value" of the receivables, and it is this figure which governs the percentage which the lender will advance against acceptable accounts to the prospective borrower. A normal figure is 80 per cent; but, regardless of the percentage of advance, the lender has the option of rejecting individual invoices. The finance credit man must approve a loan with the conviction that it is constructive and that the borrower will remain solvent and progress; but simultaneously he must regard his collateral in the light of a possible forced liquidation.

\footnotetext{
${ }^{8}$ Koessler, New Legislation Affecting Non-Notification Financing of Accounts Receivable, 44 Mrch. L. REv. $56_{3}$ (1946).

OEdward F. Gee, The Evaluation of Receivables and Inventories, c. V (1943).
} 
The other major method of security control is through supervision of collateral. This is a continuing process which requires trained personnel familiar with the practical workings of commerce and industry. After a loan has been approved and the funds have been transferred, the borrower will from time to time assign new invoices to the financial agency as the previous ones are paid out, thus making the loan a revolving cne. When the borrower makes a shipment to his customer, he sends a copy of the original invoice to the lender, attaching thereto the-original shipping document-bill of lading, trucker's receipt, postal slip, or other evidence of shipment. These documents must be reviewed carefully in order to be certain they are valid in every respect. Occasionally a simple checkup on such a small matter as the type of railroad car used in shipment will uncover the fact that the merchandise could not have been shipped in that specific type of car. While seemingly unimportant, these small discrepancies sometimes lead to further investigation and the exposure of a fraudulent assignment. The lender, too, must maintain maximum credit lines on individual customers of its client, and pass separately on the credit standing of each customer in connection with individual invoices, for the axiom reigns in the business that no client is better than his own customers. If the lender has confidence in these underlying debtors, his loan is usually safe.

There are many other matters of concern in the supervision of collateral, among the most important of which are the checking of merchandise returns, discounts, and other adjustments. These matters not only affect the value of the receivables, but also show favorable or unfavorable trends which throw light upon the over-all condition of the business. The financing of accounts receivable is a detail job, and no amount of acumen or intuition will substitute for detailed grinding. Secured financing is a low-profit venture, and losses on a single loan because of relaxation in vigilance can easily wipe out the income of an entire portfolio. The required precautions and safeguards are at times expensive, but they are a vital bulwark against loss. There can be no compromise.

Another method which lenders utilize to confirm the value of collateral is that of verification. Verification is a system of obtaining from individual debtors of a client an acknowledgment of the actual amount owing on a particular date. Under the non-notification plan, this is done by mail through the client himself or through a third party such as an accounting firm (the latter way being more satisfactory), but replies are received and opened by the lender. The verifications may be either positive or negative; that is, the debtor is either required to answer or else he need answer only if the amount shown is incorrect. Neither of these methods has proved its superiority over the other, and both serve the purpose. Any discrepancies are checked through to an acceptable conclusion.

In the revolving character of an accounts receivable loan, the client must pay the lender upon collection of his receivables. It is essential for the lender at all times to receive original debtors' checks from his client for deposit. There are three prime reasons for this procedure: First, it assures valid collection of the re- 
ceivables; second, is usually affords further proof of the original genuineness of the account; and, third, it precludes any commingling of funds by the client, which, in the event of difficulty, might set aside title of the assignee to the collateral as against a trustee in bankruptcy or intervening creditors. Upon receipt, deposit, and application of the debtors' remittances, the lender returns to his client the reserves held over and above the funds originally advanced, less any deductions by the debtors for discounts, etc. If for any reason there is an additional surplus in the debtors' checks (such as payment of an unassigned invoice), this amount is also returned to the client; likewise, any shortage which renders a remittance insufficient to cover the amount advanced by the lender is immediately payable. In the event of any returns or the issuance of credit memoranda by the client for any other reason, the client must immediately remit to the lender any amounts previously loaned against billings involved.

On occasion, in order to deal with some special aspect of a particular account and to render an added service where needed, a lender will place its own representative, or custodian, on the premises of the client on a permanent, daily basis. This is especially desirable if a factor's lien loan (which I shall discuss later) is also in effect, or where the accounts-receivable assignment commonly known as the "availability plan" is in effect. The availability plan provides for bulk assignment of all receivables by the client and the drawing down of funds as needed without regard to individual invoices. This plan eliminates much of the work-detail in assigning invoices, and is of most value where billings are voluminous or in amounts so small as to render the work burdensome and uneconomic.

The service charge of the lender may be made as a discount on the face of the individual invoices assigned, but is usually taken as a flat interest charge based on the average daily balance of either the cash advanced or the face value of invoices assigned. In either case, it is computed on a true-yield basis. Among the reputable finance companies, these rates compare favorably with those offered by other financial agencies for similar services when all costs and other factors are considered. On occasion, commercial finance companies have been criticized as being too "expensive." Although this term may apply to certain nondescript opportunists, it is not an appropriate charge when directed at the better concerns. The difficulty has been a tendency on the part of the neophyte to consider the "rate" as being the actual "cost." There is a substantial difference; let us take one example for comparison. When a company borrows on a note, it must ordinarily maintain a marginal balance on deposit during the life of the loan, and also pay the interest rate in advance. Thus a 20 per cent marginal balance and a 6 per cent discount are frequently deducted from the proceeds of the note to the borrower. The immediate effect of this method is to increase the cost of the loan from an apparent 6 per cent to an actual 8.I per cent. In addition, there is an intangible cost in borrowing on a note, due to the fact that the money is advanced in round sums for a definite period which, unfortunately, seldom agrees with the use of the money by 
the borrower. In other words, the borrower cannot spend the entire amount at once, nor can he accumulate it for payment the day before the note falls due; business can't be managed so simply. The result is that necessarily much of the money borrowed on a note must lie idle during the period of the loan, and this obviously increases the actual cost of the loan by an indefinite amount. The rate charged on accounts-receivable financing, on the other hand, is ordinarily based on the actual cash used, is billed at the end of the month, and is a true interest cost. This is accomplished by averaging the actual dollars used during the month at hand and charging for such average amount on a per diem basis. Thus, if the money is utilized for only a fraction of a month, charges are made only for the actual number of days involved, so that a client never pays for more cash than he needs.

The flexibility of this type of credit is inherent in its operation. Amounts loaned, since they are rooted to sales, are in direct proportion to a client's needs, and may be increased or decreased daily according to requirements. Since advances are self-liquidating upon collection of receivables, the borrower need not concern himself with repayment problems. He has already performed the major part of his contract upon which the collateral is pledged.

Most well-run finance companies also offer additional services to their clients for which there is no charge. Management and financial advice are freely rendered by senior executives as a routine matter, and the client is frequently aided in obtaining either customers or suppliers when he so desires. Informative news and analyses on economic conditions as they affect a borrower's industry are made available to him. And occasionally a commercial finance company will entertain additional credit to its clients on other collateral (such as fixed assets) where warranted, on a temporary, short-term basis.

\section{II}

Inventory financing has become firmly established in the past few years and is now a natural counterpart of accounts-receivable financing. There are several devices used for the implementation of inventory financing, among the most notable of which are warehouse receipts, factor's liens, and trust receipts. Each of these methods has its own advantages and peculiarities, but in general each serves the same purpose-a measurement of security to the lending agency. The advancing of funds by financial agencies against the pledge of inventories may serve one or more of several purposes, such as to finance opportune purchases, to ease the handicaps of seasonal trades, to provide for the aging or curing of certain commodities, and to eliminate the working-capital strain of mass-shipment requirements. In the case of a loan against permanent inventory levels, it is essential that the borrower show a good profit expectation, for otherwise it will be impossible to liquidate the loan in reasonable time. It is, of course, most undesirable for the financing agency to be compelled to repossess, for normally it has no facilities for resale and the merchandise is usually tabbed as distress goods, which do not bring a favorable price. This is especially true in the case of manufacturing inventories, or inventories of a 
variegated character which may have to be sold in piecemeal lots. The lender, therefore, must exercise extreme care as to the type of inventory hypothecated. Certainly nothing of an unfinished or semi-processed variety should be accepted as collateral, except on a temporary basis, nor should any item for which the market or resale value is not readily determinable. There is no common yardstick to measure a safe percentage for a lender to advance against inventories; the determination must be based entirely on his judgment in the face of the facts in individual cases. The amount may be based on cost, or it may be based on selling price, fair value, or any other of a number of common standards. As an average, it would appear that the customary loan value of inventory is about two-thirds of cost price, but this may vary considerably depending on the commodity, the market, and the strength of the borrower. ${ }^{10}$ It is the lender's duty as well as to his selfish interest to determine whether pledged merchandise has been purchased on credit, in which case he should insist that creditors be paid; otherwise the borrower is overestended creditwise by reason of double credit usage on the same articles.

The financing of inventory by means of warehouse receipts is not new, but developments in recent times have transformed it substantially. It is a system whereby a warehousing company issues an evidence of possession (warehouse receipt) to a third party, who is the lender against the collateral. The receipt itself may be either negotiable or non-negotiable, and may be issued against either fungible or non-fungible merchandise. The warehousing company thus acts as a custodian of the pledged commodity and releases it to the borrower only upon instructions from the lender. Under the terms of the agreement, the warehouseman is not responsible for the quality of the merchandise, but only for the actual count and apparent identification. Nor is he accountable for loss by fire, theft, flood, or other common insurable hazards in the absence of negligence.

There are two types of warehouses in general usage today which issue receipts for financing purposes: terminal and field. Terminal warehouses are those we think of most commonly; they comprise the premises of the warehouseman himself. It is often impractical, in the case of inventories under constant movement, to transport the goods to the warehouseman's premises; so there has developed the recent innovation called "field" warehousing, a simple device whereby the warehouseman leases space on the premises of the borrower and there maintains full control of merchandise placed under his jurisdiction. If a separate room is not available, very often a special wire fence is erected for the explicit purpose of segregating the pledged goods from those unpledged. It is common for the warehousing company to select an employee of the borrower and hire him as its custodian rather than to inject a stranger into the scene. Once in operation, the workings of a field warehouse are simple: the borrower tenders goods to his warehouseman, who issues a receipt to the lender, and the lender advances funds according to a predetermined percentage. When the borrower wishes to withdraw some of the

${ }^{10}$ Raymond J. Saulumier and Neil H. Jacoby, Financing Inventory on Field Warehouse Receipts 3 (1944). 
inventory for use in his business, he merely repays the amount loaned, whereupon the financing agency authorizes the warehouseman to release the merchandise. Ordinarily, the lender and the warehouseman will agree upon a certain "tolerance" to be granted to the pledgor so as not to handicap his operations, but in any event it is important that no merchandise be placed under warehouse receipt if it is so fast-moving as to make the operation burdensome.

Warehouse receipts have many practical advantages over other instruments of security. For example, the Uniform Warehouse Receipts Act, adopted by every state, avoids confusion and the problems of conflicting laws; the property may be sold without reference to a bankruptcy court; acknowledgment before a notary and recordation are not necessary; possession lies in a disinterested third party; and delivery of the receipt is sufficient to transfer title. ${ }^{1 x}$ No matter what the practical advantages, however, no device or legal protection is a substitute for knowledge of the collateral by the lender. It is his duty to be fully acquainted at all times with the merchandise being deposited in the warehouse, for the slightest variation in the quality of the goods may affect the value at market. Care must be taken, too, in setting the maximum credit line to be extended by the financial agency, for an over-large extension of credit.is an invitation to speculation in inventories by the borrower.

Another system of inventory financing which is growing increasingly popular of late is that called the "factor's lien" method. The title is a misnomer in some respects, since the device may be used by any financial agency, whether bank, finance company, or factor. It has a historical background in common law, but in more recent years several states ${ }^{12}$ have enacted more or less similar legislation to make it a statutory reality. During the eighteenth and ninteenth centuries the commonlaw factor, as has already been noted, was an essential middleman in commerce. Possibly to encourage his activity, the factor was granted a lien to secure his monetary advances not only on goods in his possession but also on goods said to be in his "constructive" possession. ${ }^{13}$ By 1850 it was a settled legal matter that from the moment the goods were set apart for delivery to the factor the property in them passed to the factor.

The term "factor's lien" in today's parlance refers to a method of pledging all of the inventory in bulk to a lender for an over-all loan. Separate items are not considered, but continuous bulk pledges are usually required. Nothing more diffcult is called for initially than the filing of a "notice of factor's lien" in the appropriate jurisdiction, the notice being valid ordinarily for a period of one to three years, depending upon the state in which the goods are located. Upon the filing of such a notice, a lender may take a simple security instrument in the form of a pledge

${ }^{21}$ Westey J. Schineider, Field Warehoustivg 4-5 (I94I).

${ }_{12}$ Alabama, Connecticur, Colorado, Maine, Maryland, Massachusetts, Minnesota, Michigan, Missouri, New Hampshire, New Jersey, New York, North Carolina, Ohio, Pennsylvania, Rhode Island, South Carolina, Texas, Vermont, Virginia, and West Virginia now have factor's lien statutes.

${ }^{13}$ J. Francis Ireton, "Trust Receipts and Factor's Liens," an address before the Section of Corporation, Banking and Mercantile Law of the American Bar Association, December, r945. 
mutually agreed upon, and the loan is an accomplished fact. Most states thus far have required, however, the posting of a sign at the principal entrance to the borrower's place of business, setting forth the name of the company owning the inventory and the name of the "factor" designated as such. From a practical standpoint, the operation of a factor's lien is extremely simple and easy to handle; there is no third party involved and the goods are allowed to move freely about the premises of the borrower. There is, however, considerable hazard to the lender, since he has no continuing control from day to day. A slipshod collateral position may easily develop unless great care is exercised at all times. It is customary, and essential, for the borrower to report at periodic intervals (the time varying according to cases) his purchases and shipments, together with a new moving balance of inventory on hand. These figures must be checked at regular periods by a costing method suitable to the lender. It is apparent that a factor's lien loan must be predicated upon extraordinary faith in the moral integrity and responsibility of the borrower, for the road is well cleared for his conversion of any funds advanced. In any event, the percentage of advance under a factor's lien is necessarily low, since it includes all phases of a borrower's inventory, including work-in-process and other extraneous materials frequently valueless unless used in a going business. The constant vigilance of a lender is never in greater demand than when he is lending under a factor's lien, although in most states the lender has additional security in that his lien flows to the accounts receivable created from the sale of any inventory pledged.

Trust receipts provide still another vehicle for inventory lending. Much has already been written about the Uniform Trust Receipts Act, ${ }^{14}$ and I shall not dwell upon the subject at length. Trust receipts have their most frequent usage in the automobile and domestic-appliance distributive trades. They are employed in the acquisition by the borrower of specific property for resale, and give to the lender a lien on such specific and transient property. This lien attaches to the goods only so long as they retain their inherent character in the hands of the borrower. Upon resale the lien dissipates, but attaches to the proceeds of the sale. Legally, the lender (called the "entruster") is the owner of the merchandise, and merely places it in the possession of the borrower (called the "trustee") for turnover. Although the separate trust receipts need not be recorded, the borrower and lender must file a statement each year that they intend to engage in trust-receipt financing. The trust-receipt might be used in the manufacturing field, but since there the goods ordinarily do not retain their original character it is seldom a practicable method. As in the case of a factor's lien, it is of utmost importance from the lender's viewpoint that the merchandise be checked on the floor of the borrower at frequent intervals in order to prevent any conversion, intentional or otherwise. Under a trust-

\footnotetext{
14 The following states have now adopted the Uniform Trust Receipts Act: Arizona, California, Dclaware, Connecticut, Idaho, Illinois, Indiana, Maryland, Massachusetts, Minnesota, Montana, Nevada, New Hampshire, New Jersey, New Mexico, New York, North Dakota, Oregon, Pennsylvania, South Dakota, Tennessee, Utah, Virginia, Washington, and Wyoming.
} 
receipt arrangement, as is apparent, the integrity of the borrower is a prime consideration.

Before leaving the subject of inventories, a word about insurance. Any lender has a vital interest in the insurance carried by his customer, and should ordinarily review the customer's insurance portfolio with an eye toward full coverage of any reasonable risk. If the borrower does not carry the right kind of insurance, or if he carries an insufficient amount, the lender may suffer a serious loss. It is therefore up to the financing agency to make certain that the borrower carries a full coverage in figures large enough to meet his peak requirements, and relating to various locations if the inventory is spread about different storage plants. This being provided for, the lender must then arrange to have a rider attached to the policies, designating him beneficiary as his interest may appear. It is also good practice to see that anyone else interested in the inventory (such as a warehousing company) is also included in such a rider. Such policies should, of course, be deposited with the lender.

From the tone of this article at certain points, I may have left the impression that many borrowers are untrustworthy or fraudulent. Nothing could be farther from the truth. In my experience I have found that standards among commercial borrowers are exceedingly high; unfortunately, however, there is always the occasional exception. It is against such infrequent defrauders that the financing agency must always gird itself, for a fraud loss may eradicate the profits derived from a substantial volume of honest business. We in the commercial finance industry have given this matter considerable thought over a period of many years, and I am glad to report that at least the beginnings of a Fraud Prevention Bureau are an accomplished fact. This Bureau, which, it is hoped, will offer its services to banks, has been organized under the auspices of the trade association for the industry, the National Conference of Commercial Receivable Companies, Inc. As of this writing the Bureau is still too young to proclaim success, but with the full cooperation of the entire industry, it can have no other course. When this is accomplished, a foremost deterrent to fruitful secured financing will have received a substantial blow. 